\begin{tabular}{|l|l|l||}
\hline \multicolumn{2}{|c|}{ PublisherInfo } \\
\hline \hline PublisherName & $:$ & BioMed Central \\
\hline \hline PublisherLocation & $:$ & London \\
\hline \hline PublisherImprintName & $:$ & BioMed Central \\
\hline \hline
\end{tabular}

\title{
Postcard from the party
}

\begin{tabular}{|l|l|l||}
\hline \multicolumn{2}{|c|}{ ArticleInfo } \\
\hline \hline ArticleID & $:$ & 4755 \\
\hline \hline ArticleDOI & $:$ & $10.1186 /$ gb-spotlight-20030422-01 \\
\hline \hline ArticleCitationID & $:$ & spotlight-20030122-01 \\
\hline \hline ArticleSequenceNumber & $:$ & 107 \\
\hline \hline ArticleCategory & $:$ & Research news \\
\hline \hline ArticleFirstPage & $:$ & 1 \\
\hline \hline ArticleLastPage & $:$ & 4 \\
\hline \hline & & RegistrationDate : 2003-4-22 \\
ArticleHistory & $:$ & OnlineDate \\
\hline \hline ArticleCopyright & $:$ & BioMed Central Ltd2003-4-22 \\
\hline \hline ArticleGrants & $:$ & \\
\hline \hline ArticleContext & $:$ & 130594411 \\
\hline fhis POF file
\end{tabular}


The International Genome Sequencing Consortium celebrated the "essentially complete" human genome early last week in Bethesda, Maryland, although the sequence itself is due to be formally unveiled in May. Festivities for the finished sequence were designed to coincide, more or less, with the 50th anniversary of the elucidation of the structure of the DNA molecule, and the double-birthday bash became a backslapping Who's Who of the past half-century in molecular genetics.

Francis Collins director of the National Human Genome Research Institute (NHGRI), who helped to open the ceremonies Monday, eschewed comparisons to the creation of the Corvette, TV Guide, or marshmallow peeps, all of which share a 50-year anniversary in 2003, preferring to liken the achievement of sequencing the entire human genome to scaling Mount Everest. In addition to the 30,000-feet/30,000-gene parallel, he said, in both instances there were "a lot of white knuckles along the way."

In setting the scene for two days of looking back and looking forward, Collins emphasized the importance throughout the genome project of studying ethical, legal, and social issues and of making data immediately available, free of charge, to the scientific community. Speakers throughout the twoday conference reinforced those ideals as they discussed their work.

First came the history lesson. James Watson and a recorded message from Sir Francis Crick reminisced about the pair's celebrated work, published April 25, 1953. Marshall Nirenberg discussed the early use of cell-free protein synthesis to decipher the genetic code in 1966. Stanley Cohen talked about work leading up to the first DNA cloning experiments with Herbert Boyer in 1963 and about public ruckus over the perceived dangers of genetically engineered bacteria that ensued. Nobel Laureate Phillip Sharpaddressed the discovery of RNA splicing in 1975.

Interspersed between talks, segments of an NHGRI-produced documentary, "Deciphering Nature's Alphabet," pieced together other aspects of DNA's early history through interviews. According to an NHGRI spokesperson, the video may be adapted for broadcast by PBS. Robert Sinsheimer, whose role synthesizing DNA in vitrowith Arthur Kornberg in 1967 was noted, told us that the history was good but incomplete.

At a press conference later that first day, Collins, the Department of Energy's Aristides Patrinos, and others announced to the press and the world that the human genome was essentially complete, with roughly 400 gaps remaining and one error per 100,000 base pairs. Robert Waterston of Washington University said the sequence is 300 times better than the last time they announced it. Sequence center leaders Eric Lander of the Whitehead Institute and Jane Rogers of the Wellcome Trust Sanger Institute told us that they were relieved to have the task behind them.

David Haussler of the University of California, Santa Cruz, Genome Browser, told us that his team had less time than usual to upload and analyze the newest version of the sequence - 4 days as opposed to 7 - because they wanted to give sequencers as much time as possible to finish the sequence. Later, Haussler marveled that computer-assembled information never before seen by human eyes was waiting on the world wide web for scientists to access. He reminisced about the day the draft sequence was uploaded in 2001, when one terabyte of information was accessed, although admitted that traffic was 
largely generated by science-fiction fans interested in finding the frequency with which "GATTACA" appeared in the sequence.

James Watson remembered a press conference held less than 15 years ago, at the start of the Human Genome Project (HGP). His shocker on that occasion was his announcement, without much prior consultation, that $3 \%$ of the genome project money should go to studying ethical, legal, and social issues (ELSI). Though he didn't think much about it at the time, he said, it was "probably the smartest thing I did." Calling for the same kind of attention and funding for current ELSI programs, Watson urged perspective, too, when evaluating the issue of genetic discrimination. "The people who suffer, they're already discriminated against by the genes they've got," he said, pushing for rapid and unfettered application of genetic knowledge to human health.

Bioethicist Eric Juengst of Case Western Reserve University applauded Watson's foresight, noting that that the set-aside of funds, now 5\% of HGP funding, has led to a better public understanding of the role of genomics in society and brought the USA nearer to federal legislation against genetic discrimination by employers or insurance providers.

During the remainder of the symposium, which ran through Tuesday afternoon, scientists charted the course for future discoveries in genomics with relevance to human health. Collins insisted that although human genome sequencing would be largely abandoned, much work would be done to build on the foundation of the human genome.

ENCODE (ENCyclopedia Of DNA Elements), for example, would exhaustively investigate coding and noncoding elements found in $1 \%$ of the genome. Haussler told us that his team at University of California, Santa Cruz, was involved in selecting that $1 \%$ of sequence data. Half, he said, was chosen at random, and the other half for its significance to human biology. The latter didn't generate much controversy, he added, but "there's always some lobbying." His personal pick, he said, was the FOXP2 gene, which has been loosely associated with the evolution of speech and which Anthony Monaco of the Wellcome Trust Centre for Human Genetics discussed on Tuesday. FOXP2 apparently has made the cut, Haussler reported.

Another initiative announced this week may yet draw controversy. Collins said he hopes to extend access to small molecule libraries by academic organizations, adding, "The time is ripe for public efforts in the drug development pipeline." Though Collins didn't go into all the details, not everyone agreed that such opportunities will be fruitful. Garrick Peters, president of a Salt Lake City biotech, Xponential Discoveries Inc., told us the idea was shortsighted and wondered why Collins would want to get academia into the "most expensive, least rewarding" phase of drug discovery. The answer will have to wait for another occasion. 


\section{References}

1. Powledge T: Human genome project completed Genome Biol, April 15, 2003., [http://genomebiology.com/researchnews/default.asp?arx_id=gb-spotlight-20030415-01]

2. National Human Genome Research Institute, [http://www.genome.gov]

3. Powledge T: Revisiting Bermuda Genome Biol, March 11, 2003., [http://genomebiology.com/ researchnews/default.asp?arx_id=gb-spotlight-20030311-01]

4. Birth of an Icon The Scientist, January 13, 2003., [http://www.the-scientist.com/yr2003/jan/ feat_030113.html]

5. Maher B: Judging DNA The Scientist, January 13, 2003., [http://www.the-scientist.com/yr2003/jan/ maher_p27_030113.html]

6. The Nobel Prize in Physiology or Medicine 1993 Nobel e-museum, [http://www.nobel.se/medicine/ laureates/1993/index.html]

7. Letters: Progress in the Biological Sciences The Scientist, October 14, 1996., [http://www.thescientist.com/yr1996/oct/let2_961014.html]

8. Weitzman J: The Human Genome Consortium paper: sequencing by collaborative mapping Genome Biol, February 13, 2001., [http://genomebiology.com/researchnews/default.asp?arx_id=gbspotlight-20010213-02]

9. The Internet Movie Database, "Gattaca (1997)", [http://www.imdb.com/Title?Gattaca+(1997)]

10. The National Human Genome Research Institute: A Brief History and Timeline, [http://www.genome.gov/10001763]

11. ELSI Research Program, [http://www.genome.gov/10001618]

12. Powledge T: Whither NHGRI Genome Biol, April 17, 2003., [http://genomebiology.com/ researchnews/default.asp?arx_id=gb-spotlight-20030417-02]

13. Pray L: Post-genome project launches Genome Biol, March 6, 2003., [http://genomebiology.com/ researchnews/default.asp?arx_id=gb-spotlight-20030306-01]

14. Brenner S: After the (draft) sequence Genome Biol 2001, 2:comment1006.1-1006.2., [http://genomebiology.com/2001/2/5/comment/1006] 